\title{
Territorializing Maoism
}

Dictatorship, War, and Anticolonialism in the Portuguese "Long Sixties"

I

$n$ the 1960 s and 1970s, the influence of Maoism extended all over the world, although its ideological impact has mainly been associated with certain specific national contexts. The aim of this article is to analyze the projection of Maoism in Portugal in the final years of the Estado Novo dictatorship, focusing on the intervention and discourse of the Movimento Reorganizativo do Partido do Proletariado (MRPP; Movement for the Reorganization of the Party of the Proletariat). The MRPP was not the only organization that claimed an explicit link with Maoism, but it was the one that most clearly combined an imaginary link to the Chinese Cultural Revolution with a particular mix of youth activism, triumphalism and moralism. This article explores the hypothesis that the particular constraints forged by the dictatorship and the significant impact of the colonial war produced a specific territorialization and influence of Maoism in Portugal during the first half the 1970 .

\section{The Portuguese Dictatorship and the Colonial War}

It is important to note that during the twentieth century, Portugal lived under a long dictatorship imposed at the beginning of the 1930 s within the context of the rise of philo-fascisms in Europe and defined by an antiliberal and corporative ideology. The state was governed by António 
de Oliveira Salazar until September 1968, when, already extremely frail, he was replaced as president of the council by Marcelo Caetano. Marcelismo, the term used to describe this period, lasting from September 1968 to April 1974, promised modernization and greater political openness, but this would soon be thwarted, mainly by the long impasse created by the colonial war that eroded the legitimacy of the regime and also its international reputation. ${ }^{1}$

The regime had faced armed rebellions since 1961, led by movements struggling for independence in the territories under Portuguese administration, first in Angola, in 1961, and afterward in Guinea-Bissau and Mozambique, in 1963 and 1964, respectively. With the exception of Israel, Portugal had the highest percentage of armed men in any Western country. More than a million men, approximately 800,000 of whom were from the so-called metropole, were called up to fight in Africa. This involved a human effort five times greater, in comparative terms, than the one mobilized by the United States of America during the Vietnam War. ${ }^{2}$ The war and poverty effectively drained Portuguese society: between 1957 and 1974, 900,000 Portuguese citizens emigrated to France, representing around one-tenth of the population, 550,000 of whom settled illegally in French territory. ${ }^{3}$

The apologia for the empire, compounding and reconfiguring themes that dated back to the mid-nineteenth century, was one of the main strands in the construction of a national imaginary that would be seen as indelibly linked to the golden age of the Discoveries and came to define, from the mid-1950s onward, an interpretative framework for the Portuguese colonial experience that presented it as different and more benign than the colonial experiences produced by other European powers. ${ }^{4}$ Hence most of the population viewed the start of the war with nationalist fervor inflated by one-sided reports and images of violencesuch as the massacres of Portuguese settlers committed in March 1961 by the União das Populações de Angola (Union of Angolan Peoples). ${ }^{5}$ Subsequently, the image of a "low-intensity" war was constructed, giving the impression that this simply involved "policing the territory" to neutralize specific rebel groups.

The years that followed saw growing discontent with the conflict. By the end of the 1960s in particular, certain fringes of the population had 
begun to view protest against the dictatorship and protest against the colonial war as part of the same political struggle. A new radicalized activism, which had a particular impact on educated youth, was added to the more traditional communist or republican-socialist antifascist currents. The state unleashed forms of repression against all of them, which ranged from curtailing political activities to detention, torture, and imprisonment. The Estado Novo would only be overthrown on 25 April 1974, by a military coup that would immediately lead to a fervent revolutionary process known as the "Carnation Revolution." The social mobilization that followed dismantled the repressive apparatus of the dictatorship, questioned the structure of ownership, experimented with new forms of organization and claims, won back public freedoms that had been curtailed, and witnessed the independence of the African territories, the end of the war, and the downfall of the Portuguese Empire in Africa.

Various causes may explain the popular uprising that gave rise to the two-year revolutionary period of 1974-76. The most obvious of these lies in the breakdown of the dictatorship's legitimacy in its final years. This was evident from the outset in the growing discontent with the colonial war. In fact, it was this discontent that would determine the actions of the Movimento das Forças Armadas (MFA; Armed Forces Movement), which developed rapidly from professional demands to recognition of the need to overthrow the regime. In addition, the part played by the economic crisis in undermining the regime is also a consideration-leading to a wave of strikes from the end of 1973 onward in which the Partido Comunista Português (PCP; Portuguese Communist Party) and related groups played an important role-and the process of diversification and radicalization of the left-wing opposition, mainly from 1969-70 onward. This new activism, which had a particular impact on urban and educated young people, discovered a significant sounding board in Maoism.

\section{Maoism in Portugal}

International Maoism was shaped as a result of the impact of two distinct phenomena, namely the Sino-Soviet conflict and the Cultural Revolution, which concomitantly formed the basis of two political lines, each with their own specific characteristics. ${ }^{6}$ The first wave of Maoism coincided 
with the dissent between the Chinese and the Soviets that emerged after the XX Congress of the Communist Party of the Soviet Union in February 1956. This divergence would lead to a rupture between the two countries and the appearance of small collectives aligned with China. They constructed a varied ideological repertoire, ranging from propaganda against Soviet "revisionism" to a clearer definition of a strategy and tactics that were linked to the specific national context in which they emerged. A second more obvious "Maoist" wave emerged at the end of the 1960s, influenced by the Cultural Revolution and converging with the youth movement rebellion at the end of the 1960s and beginning of the 1970 .

Maoism also emerged in Portugal at two separate times. The Frente de Acção Popular (FAP; Front for Popular Action) and Comité MarxistaLeninista Português (CMLP; Portuguese Marxist-Leninist Committee) appeared in 1964 as the result of ideological clarifications involving the PCP. The former saw itself as a mass front dedicated to overthrowing the regime, whereas the latter aimed to establish itself as an embryonic reconstructed Communist Party. The leading figure involved in this task of demarcation was Francisco Martins Rodrigues, who had taken part in the escape by Álvaro Cunhal and other communist leaders from Peniche prison on 3 January 1960 and afterward became a member of the Central Committee and Executive Committee, which led the party in Portugal. ${ }^{8}$ The crux of the dissenting position adopted by this emerging "MarxistLeninist" sector echoed the Sino-Soviet conflict, with the FAP/CMLP positioning itself in favor of the Chinese line.

In domestic terms, the dissent centered on the question of alliances (building fronts with the democratic-liberal bourgeoisie versus a "working class-peasant" alliance) and the strategy for overthrowing the regime ("national uprising" versus armed struggle).9 The group initially organized in exile in France-with branches in Algeria, Switzerland, and Belgium - and shortly afterward decided to clandestinely transfer its leading cadres to the interior of Portugal. Heavily persecuted by the Polícia Internacional de Defesa do Estado (PIDE; International State Defense Police) between 1965 and 1966, this first "Marxist-Leninist" wave practically disappeared, and its political camp was restricted to some members with a brief experience of militancy within its structures and infighting in exile. 
From 1970 onward, a number of groups influenced by Chinese theory erupted onto the scene, some of which had few or no links with the FAP and CMLP. The CMLP, based on French emigrants and militant campaigns focusing on Lisbon student circles, became the Partido Comunista de Portugal (Marxista-Leninista) [PCP (m-l); Communist Party of Portugal (Marxist-Leninist)]. Heavily defined by strict "Marxism-Leninism," it was the party that would later maintain diplomatic relations with China. In 1973, the Organização Comunista Marxista-Leninista Portuguesa (OCMLP; Portuguese Marxist-Leninist Communist Organization) was created from the merger between O Grito do Povo (The Cry of the People), which was mainly active in student circles in the cities of Porto and Coimbra, and O Comunista (The Communist), which had a presence in some emigrant groups in Europe, particularly in France but also in Holland, Sweden, and Denmark. The Comités Comunistas Revolucionários Marxistas-Leninistas (Revolutionary Marxist-Leninist Communist Committees), Unidade Revolucionária Marxista-Leninista (Marxist-Leninist Revolutionary Unity), O Bolchevista (The Bolshevist), and the MRPP were also founded in 1970. This second Maoist wave created a new militant galaxy. The majority of its members had not passed through the ranks of the PCP and had already been influenced to a certain extent by the radical student culture.

As a whole, the "Marxist-Leninist" or Maoist organizations represented the most significant current within the Portuguese far left in the final years of the dictatorship, both in terms of their dimensions and their visibility and impact. ${ }^{10}$ There are various reasons for this, which may be grouped into four main explanations. First, Maoism had the added attraction of referring to the imaginary of a frugal, egalitarian China and the political processes unfolding in what was at the time called the "Third World." Second, given its anti-imperialist stance, Maoism was particularly able to prioritize the anticolonial struggle. This issue resounded with singular emphasis on the lives of young Portuguese people who, if they had not fled the country, knew that sooner or later they would be called up for military service and sent to Africa. Third, it already had a coherent theoretical corpus, produced between 1964 and 1965, molded by texts written by Francisco Martins Rodrigues and the pages of Revolução Popular (Popular Revolution), the organ of the CMLP. Despite the differences between the first and second waves of Maoism, these 
documents allowed for an ideological demarcation to be established in relation to the PCP and offered a perspective on revolutionary action in the country.

Finally, Maoism formed part of a Leninist organizational culture that emphasized democratic centralism and secrecy, which made it more able to withstand the onslaughts of the Estado Novo-unlike organized anarchism, for example, which had practically disappeared in the country by the early 1940s. However, in relation to the more traditional communist or socialist-republican currents, the Maoist camp defended more open forms of opposition to the dictatorship, which meant that it was more enthusiastically received by youth sectors influenced by the antidisciplinary Weltanschauung. ${ }^{11}$ It offered them a new confrontational form of practice that traditional communism had not provided and an ideological grammar that combined the almost total politicization of all aspects of life with a very concrete focus on the war and ways of rejecting it. Among the Portuguese Maoist galaxy, the MRPP was the organization that most explicitly evoked the imaginary linked to the Chinese Cultural Revolution, combined youth activism with triumphalist messages, and engaged in a radicalized activism based on aggressive opposition to the colonial war. The next section observes how these elements materialized in the political language and work of the group.

\section{The MRPP: Creating through Struggle the Party That Had Never Existed}

The organization was founded at a clandestine meeting held in Lisbon on 19 September 1970, attended by Arnaldo Matos, Fernando Rosas, João Machado and Vidaúl Ferreira, which from then onward constituted the Lenin Committee, the Central Committee of the organization. The origins of the MRPP in fact date back to developments in certain youth sectors following the October 1969 elections for the National Assembly, ${ }^{12}$ and the involvement of the Esquerda Democrática Estudantil (EDE; Student Democratic Left) in the student unrest that took place in Lisbon in 196869. The roots of the EDE itself lay in the demonstration against the Vietnam War at the American Embassy on 21 February 1968, an event that aimed to have a rebound effect on the war being fought in Africa. The 
social base of the MRPP therefore consisted of radicalized young people in the capital or its outskirts, in a context in which Marcelismo had proved to be a failed project for greater openness, and the war, which had been waged for almost a decade, was heading toward a particularly critical phase.

The Law Faculty at the University of Lisbon became the most visible focus for the movement's work and recruitment, with its influence subsequently extending to other schools in Lisbon and later, from 1973 onward, to student circles in Coimbra, Porto, Braga, and Guimarães. While it is true that the student contingent was an important component within the movement, this also meant that for a long time the presence of the MRPP or structures that it developed in other areas of society, namely within the fringes of young workers in the Lisbon area and the region north of the capital, were disregarded. The organization was also active in some cultural cooperatives - until 1971-72, when they became the target of legal intervention that sought to restrict their activities-and publications such as O Tempo e o Modo (The Time and the Manner), an important magazine founded in 1963 by Catholic critics of Salazarism, which underwent a radical makeover at the end of the 1960 s that would later establish the hegemony of the MRPP in the publication.

In December 1970, the Bandeira Vermelha (Red Flag) was launched as the theoretical organ of the MRPP. It proposed a regrouping of the Marxist-Leninists, because the PCP was seen as dominated "by a fraction of the bourgeoisie that betrays and paralyses the struggle of the working class and the exploited." ${ }^{\prime 3}$ The expression "reorganization" also indicated its commitment to the Marxist-Leninist line dedicated to "reconstructing" the true Communist Party. While the document-essentially written by Fernando Rosas, a former PCP militant-valued certain moments in the history of the PCP up to 1956, it also affirmed that since its foundation in 1921, the PCP had been a "failed attempt at a Marxist-Leninist rupture with the petty bourgeois domination of the working class movement," and that its history amounted to nothing more than a "long itinerary of petty bourgeois control."14 This latter position, defended in particular by Arnaldo Matos, would become a key issue for the organization in relation to other Maoist groups. 
Although it was not the only one, the MRPP was the group most clearly identified by the use of the expression "Maoism" as its label. Despite displaying a Red Guard on its header, in February 1971 the organization's clandestine newspaper Luta Popular (The People's Struggle) only refers to itself as "the universal truth of Marxism-Leninism." ${ }^{\text {"5 }}$ However, from mid-1971 onward, slogans shaped by the Cultural Revolution began to emerge in the group's publications, and Maoism was defended as the "Marxism-Leninism of our time." ${ }^{\text {"6 }}$ The actual titles of the newspapers of the affiliated organizations, such as the Guarda Vermelha (Red Guardproduced by the Federation of Marxist-Leninist Students, an MRPP student organization), reflected this direct evocation of Maoist China. From December 1973 onward, the newspaper of the cultural organization linked to the MRPP was called Yenan, after the Chinese city where the Long March had ended and the center of the communist insurrection from 1935 to 1948. The presence of China-and the Asian struggle in general-was also evident in the type of visual documentation that was disseminated, which featured figures in the typical uniform of the Red Guards, with eyes that were more almond-shaped than those of westerners.

On 12 October 1972, José António Ribeiro dos Santos, a law student and prominent activist in the Federation of Marxist-Leninist Students (Federação de Estudantes Marxistas-Leninistas), was assassinated by agents of the DGS. ${ }^{17}$ The funeral of Ribeiro dos Santos was transformed into a significant demonstration against the regime and ended with the intervention of the police and the imprisonment of various demonstrators. ${ }^{18}$ The MRPP Central Committee approved the resolution Todos os Quadros São Servidores do Povo (All Cadres Are Servants of the People), which contained a eulogy to the "first Marxist-Leninist-Maoist who gave his life for the Proletarian Revolution and for Communism," using the language of martyrdom. The episode reinforced the hostility of the MRPP toward the PCP and the other political formations on the far left, which it called "neo-revisionists." The resolution stated that they benefited from the "favors of repression, since they not only boycotted the construction of the revolutionary party of the proletariat, but also denounced its militants." ${ }^{19}$ 
In a study on memories of activism in the MRPP, Paula Godinho clearly shows how the tragic death of Ribeiro dos Santos defined a "before and after" period in the lives of a good many ex-militants from the group. The effects of this "primordial death" created a "flesh and blood memory" that could not be forgotten and a caesura in the passage of collective and individual time. ${ }^{20}$ In a lengthy interview that took place nearly 40 years after the event, Aurora Rodrigues talked about the significance of this death "which I never got over," adding that "the people who were with me could not either." She also recalled how the memory of Ribeiro dos Santos helped her to resist interrogation at the headquarters of the political police and the torture she was subjected to, which included beatings and several days of sleep deprivation. ${ }^{21}$

Another distinctive characteristic of the MRPP was its accentuated moralism, clearly expressed in the directive Pensar, Agir e Viver como Revolucionários (Think, Act and Live Like Revolutionaries), dating from October 1972. In this document, following a case of adultery in the ranks, the Central Committee decided to launch a campaign understood as a "prophylactic" against the "microbes of bourgeois moral corruption." The main weapon against liberal ideologies had to be understood as "a vast and energetic campaign of criticism and self-criticism" of the moral and amorous behavior of militants to "eradicate from our ranks any displays of ideological, moral and political corruption." ${ }^{22}$

According to Guerreiro Jorge, one of the reasons why there was no criticism of the traditional model for marriage and relationships was due to the practical need to make houses available, in a context in which a clandestine existence was one of the key mechanisms for political action. As he states, on the basis of his own experience, "the MRPP had no structure or money for many houses. In 1972-73 many were in prison and more people needed to go into hiding...I married and the party immediately started to use my house." ${ }^{23}$ However, in addition to this eminently practical reason, value was clearly placed on a "proletarian morality" aimed at enabling militants to absorb the typical forms of behavior of the people.

In fact, the condemnation of adultery, defense of marriage, and use of appropriate sober clothing were the visible faces of the diffusion of a model of militancy based on purity, abnegation, and the idea of acting in 
line with what was understood to be the moral sentiments of the masses. ${ }^{24}$ Morally reprehensible behavior was seen as the result of damaging imperialist influences. In January 1974, an MRPP cultural organization defined Portugal as a "neocolony" in which the "jackals of imperialism" were subjecting "the Portuguese people to their decadent values, corrupt habits, pornography, prostitution, poisonous and alienating propaganda, oppression and humiliation, imperiously trampling our beloved people underfoot." 25

The importance of the commitment to anticolonialism was a key characteristic of the MRPP. It should be noted that in Portugal, criticism of the colonial war only entered the list of student demands relatively late. By the end of the 1960s, explicit opposition to the conflict in Africa was still the preserve of small groups on the far left or students who had links with the colonies, such as those who lived in the Casa de Estudantes do Império (Home of the Students of the Empire) and some of the Coimbra student houses (Repúblicas). Explicit revolt against the war only developed in student circles from 1968-69 onward. On 21 February 1970, the first demonstration was held as a direct protest against the colonial war, organized by the Comités de Luta Anticolonial (Anticolonial Struggle Committees) led by young pro-Maoists. In February 1971, the headline of the first issue of Luta Popular, the organ of the MRPP, read: "Long Live the Great, Glorious and Just Revolutionary Struggle for National Liberation of the Oppressed Peoples of the Colonies," ${ }^{\text {"26 }}$ using the triumphalist language that was a hallmark of the movement.

Although several hundred young people were involved on the appointed days, the various demonstrations against the colonial wars faced great difficulty in "getting started" or doing so with any density. ${ }^{27}$ This helps explain the explosion of a particular form of street protest, namely "flash demonstrations" (manifs-relâmpago), the first of which took place on 3 April 1973. According to Luta Popular, "several hundred young people" ran through a busy area of Lisbon, "waving red flags and placards with revolutionary slogans, throwing stones at the banks, distributing leaflets to passers-by" and shouting out slogans, such as "the People's War on the Colonial War!” At the same time, similar slogans were being painted on walls and the outsides of trams, buses, and coaches, so that, in the words of the movement itself, they would be traveling "at 
rush hour, through the central and peripheral zones of Lisbon bearing the bright red slogans of the revolutionary proletariat!"28 The introduction of this new form of political intervention was designed to avoid attacks by the police, who found it more difficult to intersect small, mobile groups, and resulted in a form of rebellion that had a greater impact and imprinted a new form of protest on the geography of the city.

An aggressive activism that was less concerned with conspiratorial caution therefore became another characteristic of the MRPP. This new style of confrontation with the authorities included organizing flash demonstrations, distributing pamphlets in broad daylight, and throwing stones at banking institutions. Arming themselves with iron bars to face the police or the aggression of the PIDE/DGS agents during demonstrations was a further illustration of the confrontational attitude of the groups. Another common practice - which also served to test the revolutionary spirit of new recruitsinvolved daubing large slogans in various locations in the city of Lisbon and gradually in other places in the country. The praise lavished on political courage, leading to actions that did not always observe the customary conspiratorial caution, helps to explain the number of militants who were imprisoned and subjected to torture-amounting to 30 in three years, some more than once. ${ }^{29}$

The image of the MRPP that has been preserved in the public memory highlights aspects of its political intervention that emerged or developed later, during the Carnation Revolution of 1974-75. In the first place, there are the huge and excellent-quality murals they produced, usually featuring the people parading in working clothes in specific poses. With its frenetic, sectarian style, this feature gave rise to the expression Meninos Rabinos que Pintam Paredes ("naughty boys who write on walls") as a pejorative description of the group..$^{30}$ Second, in the context of the imprisonment of 432 militants in May 1975, a kind of cult emerged around the party leader, Arnaldo Matos, also a prisoner. From this time onward, he would be known by the MRPP as the "Great Leader and Educator of the Working Class," and poems and murals appeared representing him in this role.

These two aspects, as well as an attitude of permanent hostility toward the PCP, shaped the prevailing image of the MRPP, downplaying the dimension and nature of the activism carried out by the group in the period before 25 April 1974. With the demise of the Estado Novo, the group made a decisive 
contribution toward establishing a new focus on opposition to the war, which until the mid-196os had been blocked by the "delayed" nature of Portuguese anticolonialism. ${ }^{31}$ This helps to explain the politicization of the Portuguese youth, within a context in which the regime was showing signs of intending to continue the war it had been waging for 13 years, and also created the specific characteristics of the political radicalism that emerged in the 1960 s and 1970 .

\section{The "Long Sixties," "International Maoism," and Anticolonialism}

The place of the Maoist phenomenon in the so-called "long sixties" is one of the aspects evoked in studies of this period, even though the interpretations are sometimes tinged with caricatures and clichés. ${ }^{32}$ In Western countries, specifically those within Europe, French Maoism gained unprecedented visibility, ${ }^{33}$ partly explained by the May 1968 uprising and political radicalism in the country and the involvement or support of leading intellectuals in Maoist or proto-Maoist movements. Conversely, the phenomenon has received less attention in other Western countries, where-given the amount of support it attracted, the originality of its forms of organization, and the political practices and discourses it expressed-it also achieved some political relevance. ${ }^{34}$ Moreover, active involvement in organizations that subscribed to this ideology is often understood as a youthful phase preceding later accommodation within the political, economic, or intellectual elites. The imagined model for this trajectory is that of the former militant who is nowadays either a media figure or works for the government or the business sector, and this is very evident in Portugal, given the endless attention paid to the brief histories of the youthful political affiliations of a handful of leading public figures. ${ }^{35}$

In addition, many observations on the Western Maoism of the period characterize it as the mere sectarian recycling of a Marxism-Leninism that essentially sought to mechanically transplant the Chinese model to other places. George Katsiaficas, in one of the first studies on the "global sixties," describes Maoism as exterior to the essential dynamics of the age. Katsiaficas believes that these years were influenced by a vague Marcusian "Eros effect" that created a clear dividing line between the "old left" and 
its "coercion methods" and the "new left" that sought to "win people's hearts and minds through persuasion." According to this scheme, the Maoists were part of a "new old left," characterized by the influence of events such as the Chinese Cultural Revolution, which had "little to do with the essential character of the movement." ${ }^{36}$ André Glucksmann-a former Gauche Prolétarienne militant and later a key figure in antitotalitarian Atlanticism-considers that ideology produces peculiar

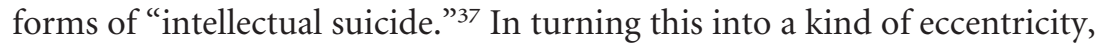
these interpretations make it difficult to understand the phenomenon in the light of what it represented in Western countries: a product of sixties radicalism assuming different contours according to the different national contexts in which it was molded.

In a different way, in "Periodizing the Sixties," an essay first published in 1984, Fredric Jameson refers to Maoism as the ideology that best translated the radical Weltanschauung, to the extent that it led to a "displacement" of the dichotomies through which communism had traditionally interpreted political antagonism: the opposite of "bourgeois" was no longer "proletarian" but "revolutionary." 38 In the Maoist camp, party membership or class background tended to be downplayed, while moral considerations concerning the refusal of privileges of any kind, identification with the ideal of proletarian life, and engagement with the fight against all forms of oppression increasingly became the criteria for political judgment.

Among these issues, the colonial question became particularly significant in some parts of the globe. The so-called "Third World" served at the time as an umbrella term under which a very different number of experiences and processes could be grouped, ${ }^{39}$ which, when combined, allowed for a radical critique of the existing situation and the simultaneous elaboration of radical alternatives. ${ }^{40}$ Thus, the struggles for independence and recognition set in motion in the "Third World" enabled connections to be made between transnational space-in which figures such as Fidel Castro, Che Guevara, Ho-Chi-Minh, and Mao Tse-tung (as well as Amílcar Cabral, Malcolm X, and Frantz Fanon) circulated-and what Christopher Leigh Connery called the "new politics of temporality." ${ }^{41}$ This was evident in aspects like the critique of labor and its rhythms, the emphasis on flows of revolutionary energy that could 
unleash the stages of development identified by classical Marxism (of which the Guevarist foco theory of guerrilla warfare and the China of the "Great Leap Forward" and the "Cultural Revolution" are the most significant examples), and the identification of new historical subjects.

\section{Shaping the Repertoire of Protest}

Particularly in Western democracies, this process intersected with the emergence of a new language of protest defined by a celebration of ambiguity and rejection of the "discipline of politics" traditionally constructed around notions like organization, hierarchy, and leadership. ${ }^{42}$ These traits were present in what A. Belden Fields terms "anti-hierarchical Maoism," which was particularly evident in France, inspired by issues such as the nature and different strands of oppression and the search for more fluid forms of organization. ${ }^{43}$ However, they were less evident in the Maoism that developed in Portuguese territory, which may be explained by a series of factors. First, the "semi-peripheral" nature of Portuguese society ${ }^{44}$ - distant both from the core developed countries and the peripheral countries-made it difficult for a postmaterialist discourse to be substantially absorbed in the same way that resounded with a certain sector of philo-libertarian European and North American youth. Interestingly, the weak urban development in the country-although this was changing at the time, with the exodus of the rural population due both to emigration and migration to the cities, and the consequent fall in employment and primary sector GDP ${ }^{45}$ - did not lead to any substantial attempts to establish Maoism in rural areas, nor to any emphasis on the emancipatory power of the peasantry. ${ }^{46}$ This can be explained by the fact that Maoism in Portugal was essentially a young urban phenomenonalthough it had some impact on intellectuals and the fringes of the working-class movement-which took the student world as its favored arena for intervention and recruitment. Second, correlating with this, the extent of the wide-ranging conservative Catholic morality also helps to explain the almost total lack of organized attitudes associated with "antidisciplinary" radicalism, which, for example, fueled the French Maoism linked with the Gauche Prolétarienne. ${ }^{47}$

Third, it is important to stress the role played by censorship and repression in restricting the type of protest that was possible, which forced 
political activities into a clandestine or semilegal existence, even interiorizing risk as a permanent feature of militant life. In fact, "punitive violence" - the complex of laws, courts, prisons, and police designed to monitor and punish dissidence-constituted a kind of second security ring that was activated whenever self-restraint in terms of obedience and order failed. ${ }^{48}$ In effect, as previously stressed, the expectations and effects of repression not only served as a constraint but were also a factor that shaped the identity of the opposition organizations in the final years of the dictatorship, above all those that had a strong student membership. ${ }^{49}$ Although state authoritarianism constrained political activity, ultimately it also endowed it with a "romantic" dimension, in which risk and courage would emerge as the elements that shaped the experience of militancy.

Finally, the role that fighting the dictatorship and, later, the colonial war played in shaping political opposition should be stressed. The authoritarianism of the Estado Novo and the physical and psychological risk that the armed conflict in Africa introduced into the lives of each young person and, by extension, their circle of family and friends, significantly overdetermined the repertoire of protest. These were the strands that would structure Portuguese left-wing radicalism in the first half of the 1970s, relegating other political and cultural forms of combat to secondary concerns.

\section{Conclusions}

Anchored in the radicalized youth sectors, Maoism incorporated a recognition of events, figures, and proposals that rejected the postwar geopolitical supremacies and advocated the need for profound and revolutionary political change. As one of the components of the far left that found international expression during the "long sixties," the way in which it materialized locally was, however, sensitive to the social formations, political contexts, and concrete challenges presented in each national context.

In Portugal, Maoism therefore acquired certain characteristics of its own, resulting from the specific circumstances of the country at the time, including that it was governed by a dictatorship that, against the tide of 
history, was engaged in a war in Africa to preserve its empire. Among the Maoist groups that emerged in the country, the MRPP was the most visibly active in Lisbon and its surroundings: it advocated an aggressive style of political intervention very much based on triumphalism and militant courage that converged with certain conservative positions regarding behavior, through which it sought to emphasize an imagined "proletarian morality." However, the central aspect that shaped its intervention was clearly the fight against the colonial war, which helped to define a new model for opposing the Portuguese Estado Novo dictatorship, thus territorializing an ideology expressed in various different ways throughout the world during the 1960s and 1970s.

\section{NOTES}

The author wishes to thank Rui Bebiano, Bruno Sena Martins, and the anonymous reviewers for their comments on an earlier version of this text. This work was supported by the Portuguese Foundation for Science and Technology under Grants SFRH/BD/22796/ 2005 and IF/00757/2013/CP1164/CTooo4.

1. Fernando Rosas and Pedro Aires Oliveira, A Transição Falhada: O Marcelismo e o Fim do Estado Novo (Lisbon: Editorial Notícias, 2004). For a concrete example of this, see Norman McQueen and Pedro Aires Oliveira, “'Grocer Meets Butcher’: Marcello Caetano's London Visit of 1973 and the Last Days of Portugal's Estado Novo," Cold War History 10, no. 1 (2009): 29-50. On the "International Dimensions of Portuguese Late Colonialism and Decolonization," see the special issue with this title of Portuguese Studies 29, no. 2 (2013), edited by Miguel Bandeira Jerónimo and António Costa Pinto.

2. John P. Cann, Counterinsurgency in Africa: The Portuguese Way of War, 1961-1974 (Westport, CT: Greenwood Press, 1997), 106.

3. Victor Pereira, "Les réseaux de l'émigration clandestine portugaise vers la France entre 1957 et 1974," Journal of Modern European History 12, no. 1 (2014): 108.

4. This construct owes a great deal to the adoption of Lusotropicalism, a theory developed by the Brazilian Gilberto Freyre that was well received in Portugal, replacing, in the 1950s, the more obviously racist theories used to justify the legitimacy of the "Portuguese Colonial Empire." Citing the innate capacity of the Portuguese for miscegenation and cultural interpenetration, Lusotropicalism was adopted by the elites within the regime but also featured widely in mass culture in the final years of the 
dictatorship. At the same time, the theory was deployed to resist international demands that the country should introduce decolonialization. On Lusotropicalism, see Marcos Cardão and Cláudia Castelo, Gilberto Freyre. Novas leituras do outro lado do Atlântico (São Paulo: Edusp, 2015).

5. On the political role of these images, see Afonso Ramos, "Angola 1961, o horror das imagens," in O Império da Visão: Fotografia no Contexto Colonial português (1860-1960), ed. Filipa Lowdes Vicente (Lisboa: Edições 70), 397-432.

6. "Maoism" was primarily a term used to describe the ideology produced and inspired by Mao Tse-tung and developed by the Chinese Communist Party. Self-defined as an adaptation of Marxism-Leninism to the particular conditions of China, its most obvious features include an emphasis on the peasantry as the driving force behind social change, a focus on the anti-imperialist struggle, and a voluntarist perception of the revolutionary change. Although Maoism refers to the specific experience of China before and after 1949, it would also be used to designate a political field composed of a group of organizations that emerged throughout the world in the 196os and 1970s.

7. The Soviet strategy of "peaceful coexistence" was therefore criticized by the Chinese for softening the necessary separation between communism and capitalism, making concessions to the postwar balance of power and abandoning the path to revolutionary change. See, for example, Long Live Leninism (Peking: Foreign Languages Press, 1960); and A Proposal Concerning the General Line of the International Communist Movement (Peking: Foreign Languages Press, 1963). It should be noted that Chinese texts openly criticizing the Soviet economic model already existed prior to these, such as the document "On the Ten Great Relations” of 25 April 1956.

8. His critique of the PCP line is explained in the pamphlet Luta Pacifica e Luta Armada no nosso Movimento, dating from 1963/64, among other documents. See João Madeira, ed., Francisco Martins Rodrigues. Documentos e papéis da clandestinidade e da prisão (Lisbon: Ela por Ela and Abrente Editora, 2015). For a view of this first "pro-Chinese" wave, cf. José Pacheco Pereira, “O Um Dividiu-se em Dois." Origens e Enquadramento internacional dos movimentos pró-chineses e albaneses nos países ocidentais e em Portugal (1960-65) (Lisbon: Alêtheia Editores, 2008).

9. This thesis was concretized by Álvaro Cunhal in the report Rumo à Vitória (Towards Victory), from April 1964, and would be established at the VI Congress of the PCP, which took place the following year in Kiev. Based on the idea that Portugal had a dependent but simultaneously monopolist elite supported by the colonial bourgeoisie, the PCP proposed a policy of antifascist alliances that would lead, via an uprising, to 
"democratic and national revolution," led by a broad social front that included the liberal and democratic sectors.

10. Maoism would remain important within the framework of the Portuguese far left during the Carnation Revolution. In fact, Portugal is possibly the only European country to have elected a member of parliament (MP) representing a party from this camp—the pro-Albanian União Democrática Popular (UDP; People’s Democratic Union). This happened in the 25 April 1975 elections for the Constituent Assembly, in a context in which other parties with a social and political presence, such as the MRPP, were prevented from standing — and the UDP managed to keep its MP in the electoral disputes that followed.

11. On the concept of "antidisciplinary protest" in the sixties, see Julie Stephens, Anti-Disciplinary Protest: Sixties Radicalism and Post-Modernism (Cambridge: Cambridge University Press, 1998).

12. From 1945 onward, within the international context of the defeat of Nazi-fascism, the Estado Novo allowed lists to be presented for election campaigns. However, the regime did not allow political parties to exist (with the exception of the single party União Nacional [National Union]), the lists were only effective for the 30 days of the election campaign, and only men aged over 21 who were heads of households, knew how to read and write, and paid a certain amount in contributions to the state could vote, together with a very restricted number of women. Moreover, the electoral roll contained inconsistencies and various frauds were reported. For a comparative perspective on the role of elections in nondemocratic regimes, see Manuel Loff, "Natureza, funções e efeitos das eleições em regimes ditatoriais: o Estado Novo em perspectiva comparada," in Eleições e sistemas eleitorais no século XX português: uma perspectiva histórica e comparativa, ed. André Freire (Lisbon: Colibri, 2011), 135-208.

13. "Reorganizar o Partido Revolucionário do Proletariado," Bandeira Vermelha 1, December 1970.

14. "Reorganizar o Partido Revolucionário do Proletariado."

15. "Reorganizar o Partido Revolucionário do Proletariado"; and "Viva a Grande, Gloriosa e Justa Luta Revolucionária da Libertação Nacional dos Povos Oprimidos das Colónias," Luta Popular 1, February 1971.

16. Guarda Vermelha 1, June 1971; and Luta Popular 5, October 1971.

17. Directorate-General for Security, the name for the political police from 1969 onward; prior to this, it was known as the PIDE.

18. Miguel Cardina, Margem de Certa Maneira. O maoismo em Portugal (1964-1974) (Lisbon: Tinta-da-China, 2011), 82-83. For a general reflection on funeral rituals and 
politics in the Portuguese twentieth century, see Diego Palacios Cerezales, "Ritual funerario y política en el Portugal contemporáneo," in Políticas de la muerte. Usos y abusos del ritual fúnebre en la Europa del siglo XX, ed. Jesús Casquete and Rafael Cruz (Madrid: La Catarata, 2009), 39-72.

19. “Todos os Quadros São Servidores do Povo,” Comité Lenine do MRPP, October 1972.

20. Paula Godinho, "Passados Insubornáveis: acontecimento, razão escrita e memórias fracas," in Ditaduras e Revolução. Democracia e Políticas da Memória, ed. Manuel Loff, Filipe Piedade, and Luciana Soutelo (Coimbra: Almedina, 2015), 145-67.

21. Aurora Rodrigues, Gente Comum. Uma História na PIDE (compilation, introduction, contextualisation, and notes by António Monteiro Cardoso and Paula Godinho) (Castro Verde: 100 Luz, 2011), 72-76, 115.

22. "Pensar, Agir e Viver como Revolucionários," Comité Lenine do MRPP, October 1972.

23. Guerreiro Jorge, interviewed by author, 24 October 2007, audio recording.

24. There are various international examples of different Maoist groups adopting "morally purist" standards of behavior, the clearest and most extreme case being that of the "communist marriages" practiced by the Italian members of Servire il Popolo. See Eros Francescangeli, "The Bride in Red: Morality and Private Relationships in the Italian Revolutionary Left- the Case of the Maoist Group Servire il popolo," European Review of History: Revue européenne d'histoire 22, no. 1 (2015): 101-19.

25. "Viva a Solidariedade Activa e Militante dos Povos de Portugal e das Colónias!” Yenan 2, January 1974.

26. "Viva a Grande, Gloriosa e Justa Luta Revolucionária da Libertação Nacional dos Povos Oprimidos das Colónias," Luta Popular 1, February 1971.

27. See Luta Popular 2, March 1971; Luta Popular 6, February 1972; Luta Popular 8, August 1972; and Luta Popular 11/12, May/June 1973.

28. Luta Popular 11/12, May/June 1973.

29. António Monteiro Cardoso, "Um tempo, um contexto," in Rodrigues, Gente Comum. Uma História na PIDE, 47.

30. On the MRPP mural paintings, see André Carmo, "Revolutionary Landscapes: The PCTP/MRPP Mural Paintings in the Lisbon Metropolitan Area," Finisterra 92 (2011): 25-41.

31. Fernando Rosas, "O anticolonialismo tardio do antifascismo português," in O Adeus ao Império. 40 Anos de Descolonização Portuguesa, ed. Fernando Rosas, Mário Machaqueiro, and Pedro Aires Oliveira (Lisbon: Veja, 2015), 13-24.

32. Arthur Marwick, The Sixties: Cultural Revolution in Britain, France, Italy and the United States, c.1958-1974 (Oxford: Oxford University Press, 1998). For an analysis focusing on 
Portugal, see Rui Bebiano, O Poder da Imaginação. Juventude, rebeldia e resistência nos anos 60 (Coimbra: Almedina, 2003). According to Fredric Jameson, the sixties would have begun in the middle of the previous decade, with the decolonialization movement in British and French Africa, and ended around 1972-74, when North America stopped sending troops to Vietnam and a new world economic crisis emerged. Fredric Jameson, "Periodizing the 6os," in 6os without Apology, ed. Sohnya Sayres et al. (Minneapolis: University of Minnesota Press, 1984), 178-209. In The Spirit of '68, a work that is interesting for its consideration of southern Europe, despite its weak contextualization of the Portuguese case, Gerd-Rainer Horn identifies the end of the era as around 1976, indicating the end of the Portuguese revolutionary experience as one of the markers. Gerd-Rainer Horn, The Spirit of '68: Rebellion in Western Europe and North America, 1956-1976 (Oxford: Oxford University Press, 2007).

33. See, for example, A. Belden Fields, Trotskyism and Maoism: Theory and Practice in France and the United States (New York: Autonomedia, 1988); M. Dressen, De L'amphi à L'établi. Les étudiants maoïstes à l'usine (1967-1989) (Paris: Belin, 1999); D. Reid, "Établissement: Working in the Factory to Make the Revolution in France," Radical History 88 (2004), 83-111; Julian Bourg, "The Red Guards of Paris: French Student Maoism of the 1960s," History of European Ideas 31 (2005): 472-90; Christophe Bourseiller, Les Maoïstes. La folle histoire des gardes rouges français (Paris: Belin, 2008); Aavv, "Prochinois et maoïsmes en France (et dans les espaces francophones)," Dissidences 8 (2010); and Richard Wolin, The Wind from the East: French Intellectuals, the Cultural Revolution, and the Legacy of the 1960s (Princeton, NJ: Princeton University Press, 2010). In addition, see the militant memoirs dedicated to the more general theme of political or student radicalism, containing information and analyses of Maoism, or the work of leading intellectuals who became involved with Maoism at a particular time-Louis Althusser, Jean-Paul Sartre, and Michel Foucault—or to some extent still lay claim to it, such as Alain Badiou.

34. See, for example, Hans Petter Sjøli, "Maoism in Norway: And How the AKP (m-1) Made Norway More Norwegian," Scandinavian Journal of History 33, no. 4 (2008): $478-90$.

35. See, for example, Clara Viana, "Ex-maoistas, uma história de sucesso," Pública, 15 August 2004; Nuno Ramos de Almeida, "O charme discreto do maoismo português," jornal I, 2 July 2011; and Paulo Chitas, "Maoistas de certa maneira," Visão, 14-20 March 2013. The constant references to MRPP militancy in the career of José Manuel Durão Barroso, former prime minister of Portugal, former president of the European Commission, and currently chairman at Goldman Sachs, is an example of this, 
frequently serving as a kind of interpretative paradigm for the political development of former Maoists.

36. George Katsiaficas, The Imagination of the New Left: A Global Analysis of 1968 (Boston: South End Press, 1987), 25-26, 71.

37. André Glucksmann and Raphael Glucksmann, O Maio de 68 explicado a Nicolas Sarkozy (Lisbon: Guerra e Paz, 2008), 118.

38. Jameson, "Periodizing the 6os," 178-209.

39. On "third worldism" and radicalism in the "long sixties," see Samantha Christiansen and Zachary Scarlett, eds., The Third World in the Global 1960s (New York: Berghahn Books, 2013). On "third worldism" in European societies with a history of development similar to Portugal but without the burden of the colonial war, see Kostis Kornetis, “'Cuban Europe'? Greek and Iberian tiersmondisme in the 'Long 1960s'," Journal of Contemporary History 50, no. 2 (2015): 486-515.

40. Christoph Kalter, "A Shared Space of Imagination, Communication, and Action: Perspectives on the History of the 'Third World', ' in The Third World in the Global 1960s, 23-38.

41. Christopher Leigh Connery, "World Sixties," in Worlding Project: Doing Cultural Studies in the Era of Globalization, ed. Rob Wilson and Christopher Leigh Connery (Berkeley, CA: North Atlantic Books, 2007), 77-107.

42. Stephens, Anti-Disciplinary Protest.

43. Fields, Trotskyism and Maoism.

44. On Portugal as a "semi-peripheral" country, see Boaventura de Sousa Santos, "O Estado, as relações salariais e o bem-estar social na semiperiferia: o caso português," in Portugal: Um retrato singular, ed. Boaventura de Sousa Santos (Porto: Afrontamento, 1993).

45. Between 1960 and 1973, the population in the interior of the country shrank, to a great extent due to emigration but also the rural exodus to the major cities. In the same period, employment in the primary sector fell from 43.6 percent to 26 percent. See Manuel Loff, "Marcelismo e ruptura democrática no contexto da transformação social portuguesa dos anos 1960 e 1970," Espacio, Tiempo y Forma 19 (2007): 139-78.

46. It is important to emphasize, in this respect, the process of "implantation" that the OCMLP aimed to introduce, transferring young people, mainly students, to popular areas to carry out political work, even though the main focus was to channel them into working-class areas. On implantation, see Miguel Cardina, Margem de Certa Maneira. O maoismo em Portugal (1964-1974) (Lisbon: Tinta-da-China, 2011), 179-215. On établissement in France, see Dressen, De l’amphi à l'établi; Reid, “Établissement,” 83-111. 
47. Fields, Trotskyism and Maoism, 120-30. Some traces of this type of activism were evident, however, in groups such as O Comunista, although they were mainly composed of exiles and Portuguese immigrants in France.

48. Fernando Rosas, Salazar e o Poder. A arte de saber durar (Lisbon: Tinta-da-China, 2012), 183-210.

49. Guya Accornero, "La répression politique sous l'Estado Novo au Portugal et ses effets sur l'opposition estudiantine, des années 1960 à la fin du régime," Cultures and Conflits 89 (2013): 93-112. See also Miguel Cardina, A Tradição da Contestação. Resistência Estudantil em Coimbra no Marcelismo (Coimbra: Angelus Novus, 2008); José Manuel Lopes Cordeiro, “'Ao serviço do povo venceremos.' A oposição estudantil nos últimos anos do fascismo (1969-1974)," Boletim Cultural de Vila Nova de Famalicão 5 (2009): 119-58; and Guya Accornero, "Contentious Politics and Student Dissent in the Twilight of the Portuguese Dictatorship: Analysis of a Protest Cycle," Democratization 20, no. 6 (2013): 1036-55. 